\title{
Artikel
}

\section{De inningspraktijk bij verkeersboetes, rijp voor verandering: is de rechtsbescherming voldoende gewaarborgd?}

\author{
Mr. dr. J.W. van der Hulst*
}

\section{Inleiding}

Sinds 1990 worden eenvoudige verkeersovertredingen afgedaan krachtens de Wet administratiefrechtelijke handhaving verkeersvoorschriften (Wahv). Bij deze bestuurlijke afdoening wordt een geconstateerde verkeersovertreding afgedaan met een voor deze overtreding toepasselijke verkeersboete, genoemd in de bijlage bij de Wahv. ${ }^{1}$ Indien de betrokkene aan wie een verkeersboete is opgelegd deze niet tijdig betaalt, wordt het bedrag van de verkeerboete van rechtswege verhoogd. Daarna mag de officier van justitie verhaal nemen op goederen, inkomsten en vermogen van de betrokkene en nadien mogen dwangmiddelen worden ingezet om de betrokkene tot betaling van de sanctie te brengen. Daarbij is de gijzeling het meest ingrijpende dwangmiddel, omdat de betrokkene in hechtenis wordt gehouden totdat hij de opgelegde verkeersboete betaalt. Althans, indien de kantonrechter een daartoe gevraagde machtiging van de officier van justitie heeft verleend. De afgelopen jaren is gebleken dat kantonrechters minder snel dan vroeger deze machtiging verlenen in verband met de financiële onmacht van de betrokkene om de opgelegde verkeersboete(s) te kunnen betalen. Tevens heeft de Nationale Ombudsman in een recent rapport geconcludeerd dat in de gangbare praktijk van het voorberei-

Mr. dr. J.W. van der Hulst is universitair docent bij de sectie strafrecht van de Erasmus Universiteit Rotterdam.

1. Laatstelijk gewijzigd bij besluit van 2 december 2015, Stb. 2015, 500. den, vorderen en ten uitvoer leggen van gijzeling de mensenrechten onvoldoende worden gerespecteerd. Deze conclusie baart zorgen omdat het bij gijzeling gaat om vrijheidsbeneming van de betrokkene. In veel van deze zaken is niet zozeer sprake van betalingsonwil alswel betalingsonmacht bij de betrokkene, zodat de gijzeling niet leidt tot het beoogde doel, namelijk de betaling van de verkeersboete, maar veeleer tot verslechtering van de toch al waarschijnliijk bescheiden financiële middelen van de betrokkene. ${ }^{2}$ Bovendien volgt gijzeling aan het einde van een streng inningstraject, waarbij het bedrag van de verkeersboete al aanzienlijk is verhoogd. Dit draagt in aanzienlijke mate bij an de betalingsonmacht van de betrokkene voordat gijzeling wordt toegepast.

Deze problematiek is terug te voeren op de inrichting van de Wahv-afdoening die een reactie was op het falende incassobeleid van verkeersboetes die voor 1990 strafrechtelijk werden afgedaan (paragraaf 2). In plaats daarvan is een afdoening gekomen met een hybride karakter (paragraaf 3), wat vragen oproept over de rechtsbescherming (paragraaf 4). Daarnaast zijn na invoering van de Wahv administratiekosten ingevoerd (paragraaf 5) en de bedragen van de verkeersboetes en de daarop van toepassing zijnde verhogingen aanzienlijk gestegen (paragraaf 6). Het gaat in steeds meer zaken om forse bedragen (meer dan € 1.000) die niet (volledig) betaald kunnen worden ook niet door de inzet van dwangmiddelen (paragraaf 7). Het is dan ook geen toeval dat juist bij de toepassing van gijzeling problemen ontstaan (para- 
graaf 9). Om deze problemen het hoofd te kunnen bieden lijkt een herijking van de bestaande gijzelingspraktijk onontkoombaar. Aan het einde van deze bijdrage zal daartoe een aanzet worden gegeven (in paragraaf 12).

\section{De Wahv-afdoening van verkeersboetes}

Het doel van de in 1990 ingevoerde Wahv was een vereenvoudiging aan te brengen in de wijze van afdoening van veelvoorkomende verkeersovertredingen van lichte aard, die eenvoudig zijn te constateren en die geen letsel aan personen of schade aan goederen (art. 2 lid 1 Wahv) veroorzaken. ${ }^{3}$ De afdoening van deze overtredingen was tot dan toebedeeld aan het strafrechtelijk apparaat. Dat had als nadeel dat de werklast van politie, het Openbaar Ministerie en de rechterlijke macht onder druk kwam te staan en dat de inning van verkeersboetes weinig effectief was en de strafrechtelijke procedure te lang duurde. Deze effecten werden versterkt door de passieve houding van veel verkeersovertreders die in meer dan $80 \%$ van de gevallen niet reageerden op een oproep om ter zitting te verschijnen en daarna de onherroepelijk opgelegde verkeersboete niet betaalden. ${ }^{4}$ Het systeem van strafrechtelijke afdoening stelde de verkeersovertreder in staat de daadwerkelijke tenuitvoerlegging van de opgelegde verkeersboete te ontlopen, eenvoudigweg door niets te doen. ${ }^{5}$ Met de invoering van de Wahv werd deze strafrechtelijke afdoening vervangen door een bestuurlijke afdoening van lichte verkeersovertredingen. Met deze wijze van afdoening werd vooral beoogd om de bestaande ineffectiviteit in de tenuitvoerlegging van opgelegde verkeersboetes weg te nemen. ${ }^{6}$

Dit bracht met zich dat de verkeersovertreder voortaan zelf actie dient te ondernemen om een hem krachtens de Wahv opgelegde verkeersboete aan te vechten door het instellen van beroep tegen deze oplegging bij achtereenvolgens de officier van justitie (art. 6 lid 1 Wahv), de kantonrechter na zekerheidstelling voor het bedrag van de opgelegde verkeersboete(s) (art. 9 lid 1 jo. 11 lid 1 Wahv) en, indien de geldboete meer bedraagt dan $€ 70$, door het instellen van hoger beroep bij het Hof Arnhem-Leeuwarden (art. 14 lid $1 \mathrm{Wahv}){ }^{7}$ Indien geen beroep wordt ingesteld of het ingestelde beroep wordt afgewezen is de oplegging van de verkeersboete onherroepelijk en dient deze binnen twee weken te worden betaald (art. 23 lid 1 Wahv). ${ }^{8}$ Er kan enkel nog verzet tegen de wijze van tenuitvoerlegging worden ingesteld (art. 26 lid 3, 27 lid 6 Wahv en voor het hoger beroep

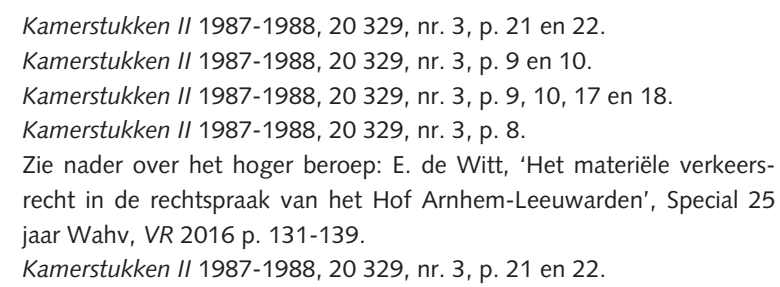

art. 26a lid 1 Wahv), maar dit raakt niet meer de oplegging van de verkeersboete als zodanig. ${ }^{9}$

De wetgever heeft de appelgrens van $€ 70$ voor hoger beroep bij het Hof Arnhem-Leeuwarden ingevoerd om het beroep op de rechter voor eenvoudige zaken te beperken tot één instantie om de toenemende druk op de rechterlijke organisatie in te dammen. ${ }^{10}$ Volgens Sackers is deze appelgrens niet meer van deze tijd. De appelgrens bij strafrechtelijke overtredingen ligt lager (€ 50, art. 404 lid 2 achter b Sv) en de Algemene wet bestuursrecht $(\mathrm{Awb})$ kent in het geheel geen appelgrens bij het instellen van (hoger) beroep tegen de oplegging van een bestuurlijke boete (art. $8: 3 \mathrm{t} / \mathrm{m}$ 8:5 en art. 8:104 Awb). Sackers bepleit daarom aansluiting bij wat elders in het bestuurlijk sanctierecht gebruikelijk is. ${ }^{11}$

\section{Het hybride karakter van de Wahv-afdoening}

Dit pleidooi van Sackers staat niet op zichzelf. Hij roept op tot een heroverweging van andere onderdelen van de Wahv-afdoening die afwijken van algemene regelingen in de Awb. Het gaat dan om onder meer het vereiste van zekerheidstelling voordat beroep mag worden ingesteld bij de kantonrechter, de aanzienlijk verhogingen bij niet tijdige betaling van de opgelegde verkeersboete en de voorziene toepassing van dwangmiddelen. ${ }^{12}$ In de huidige situatie bevat de Wahv een op zichzelf staande afdoening van verkeersboetes die is losgekoppeld van de strafrechtelijke afdoening maar ook losstaat van algemene regelingen die het bestuurlijk sanctierecht vormgeven. Het eerste blijkt uit artikel 2 lid 1 Wahv dat voorzieningen van strafrechtelijke en strafvorderlijke aard uitsluit. Daarnaast is de Awb leidend voor de Wahv-afdoening, tenzij daar in de Wahv zelf van wordt afgeweken. En dit laatste komt vaak voor. ${ }^{13}$ Sackers wijst erop dat de krachtens de Wahv opgelegde verkeersboetes eigenlijk bestuurlijke boetes zijn en dat inmiddels regelingen voor het opleggen en innen van bestuurlijke boetes hun plaats hebben gekregen in de Awb. Een herpositionering van de Wahv-afdoening is wenselijk door een keuze te maken tussen strafrechtelijke afdoening of bestuurlijke handhaving. Indien voor het laatste wordt gekozen is harmonisering met het boeterecht uit de Awb het meest logisch. ${ }^{14}$ Deze opvatting verdient steun omdat de wetgever de Wahv-afdoening bewust heeft ontdaan van strafrechtelijke invloeden en al bij invoering van de

9. Zie voor een uitzondering: HR 17 juli 1995, NJ 1995, 697 m.nt. MS en Rb. Limburg 2 maart 2015, ECLI:NL:RBLIM:1714.

10. Kamerstukken II, 1997-1998, 25 927, nr. 3, p. 6.

11. H.J.B. Sackers, 'De Wet Mulder mag geen kathedraal van de twintigste eeuw worden', Special 25 jaar Wahv, VR 2016, p. 88.

12. H.J.B. Sackers, 'De Wet Mulder mag geen kathedraal van de twintigste eeuw worden', Special 25 jaar Wahv, VR 2016, p. 86-88.

13. J.W. van der Hulst, 'De Wet Mulder en de Algemene wet bestuursrecht', In: J.W. van der Hulst (red.), De Wet Mulder in bedrijf, p. 68.

14. H.J.B. Sackers, 'De Wet Mulder mag geen kathedraal van de twintigste eeuw worden', Special 25 jaar Wahv, VR 2016, p. 89-90. 
Wahv heeft gekozen voor een bestuurlijke afdoening van lichte verkeersovertredingen. Een betere aansluiting bij algemene regelingen in de Awb voor het opleggen van bestuurlijke boetes is gewenst.

\section{De bestuurlijke (Wahv-)boete}

Tevens staat de Wahv aan de basis van de groei van het handhaven door het bestuur door het opleggen van bestuurlijke boetes. Deze groei is in het algemeen toe te schrijven aan de opvatting dat het bestuur de meest aangewezen autoriteit is voor de handhaving van beleidsinstrumentele regelgeving en daarmee in de plaats kan treden van strafrechtelijke handhaving dat pas als laatste in aanmerking komt. ${ }^{15}$ Het relatieve succes van de handhaving via de Wahv maakte duidelijk dat de bestuurlijke boete een serieus alternatief was voor de overbelaste strafrechtelijke handhaving en daarmee kan worden beschouwd als een systeemdoorbraak. ${ }^{16}$ Maar de oplegging van een bestuurlijke boete is ook bekritiseerd. Het zou kunnen leiden tot een ongewenste concentratie van bevoegdheden omdat normstelling, uitvoering, toezicht en sanctieoplegging bij een en hetzelfde bestuursorgaan worden ondergebracht. Hierdoor kan er te weinig tegenspraak worden geboden, wat afbreuk doet aan de vereiste objectiviteit en distantie bij het opleggende bestuursorgaan dat een financieel belang zou kunnen hebben bij de handhaving, waardoor het risico op misbruik op de loer ligt. ${ }^{17}$ Het strafrecht is nodig als sluitstuk van de bestuurlijke handhaving omdat kernbeslissingen over handhaving dienen te worden genomen door een onafhankelijke, onpartijdige magistraat. ${ }^{18}$ En vanuit een oogpunt van rechtsbescherming moet de bestuurlijke boete worden opgevat als een bestraffende sanctie die moet worden gerekend tot strafrecht in ruime zin. Dit impliceert een niveau van rechtsbescherming dat gelijkwaardig zou moeten zijn aan dat in de strafrechtelijke afdoening. ${ }^{19}$ Andere auteurs staan minder kritisch tegenover het vermeende tekort aan rechtsbescherming bij de bestuurlijke handhaving. De bestuursrechter is inmiddels goed in staat om tegenwicht te bieden aan het handhavende bestuur en de bestuurlijke handhaving zou in sommige opzichten zelfs meer rechtsbescherming bie-

15. A. Mein, De boete uit balans (diss. Rotterdam), Den Haag: Boom Lemma 2015, p. 44

16. G.J.M. Corstens, 'Bestuurlijke boeten in de vierde tranche Awb', NJB 2000/24, p. 1185 en R. Stijnen, Rechtsbescherming tegen bestraffing in het strafrecht en het bestuursrecht, Een rechtsvergelijking tussen het Nederlandse strafrecht en het bestraffende bestuursrecht, mede in Europees perspectief (diss. Rotterdam), Deventer: Kluwer 2011, p. 1 en 2.

17. G.J.M. Corstens, 'Bestuurlijke boeten in de vierde tranche Awb', NJB 2000/24, p. 1188.

18. N.J.M. Kwakman, 'De bestuurlijke boete: publiekrechtelijke eigenrichting, NTB 2006/47', p. 337-338.

19. C.L.G.F.H. Albers, 'De bestuurlijke boete. Magische lijn of hellend vlak?', JB Plus, 2000/4, p. 140 den dan het strafrecht. ${ }^{20}$ En met de invoering van de OM-strafbeschikking zou er geen wezenlijk verschil meer zijn in de toetsing van de strafrechter van deze beschikking en de bestuursrechter van de bestuurlijke boete. ${ }^{21}$ Ondanks deze optimistische opvattingen lijkt het onderscheid tussen bestuurlijk handhaven en strafrechtelijk handhaven minder duidelijk geworden. Hartmann waarschuwt daarom voor het ontstaan van $f u z z y$ law op het grensgebied tussen bestuursrecht en strafrecht. ${ }^{22}$ Dit bemoeilijkt het vinden van een adequaat niveau van rechtsbescherming dat bij bestuurlijke handhaving in acht moet worden genomen. Dit niveau moet overigens blijvend in de gaten worden gehouden al was het maar omdat bestuurlijk handhaven zo vaak voorkomt. ${ }^{23}$

Zoals nog zal blijken zijn deze waarschuwingen relevant voor de gijzeling wegens niet betaalde verkeersboetes. Voorafgaand hieraan wordt eerst een aantal specifieke onderdelen van de Wahv-afdoening behandeld omdat die van invloed (kunnen) zijn bij de toepassing van deze gijzeling.

\section{Verkeersboete en administratiekosten}

Naast het bedrag van de verkeersboete moeten administratiekosten worden betaald (art. 21 lid 1 Wahv). Deze administratiekosten bedragen met ingang van 1 januari $2016 € 9$ per opgelegde verkeersboete. ${ }^{24}$ Deze kosten zijn bedoeld als een bijdrage aan de financiering van de justitiële handhaving en is als het gaat om opgelegde verkeersboetes bedoeld als dekking van de kosten van tenuitvoerlegging van de verkeersboetes. ${ }^{25}$ Deze regeling is dus ingevoerd vanuit begrotingstechnische redenen en bedoeld om de inningskosten van verkeersboetes af te wentelen op de burgers. ${ }^{26}$ Een antal betrokkenen heeft tegen deze invoering van administratiekosten beroep ingesteld en aanvankelijk is dit beroep een enkele keer gehonoreerd. ${ }^{27}$ Het Hof Leeuwarden is als hoogste Wahv-rechter echter van oordeel dat de doorberekening

20. R. Stijnen, Rechtsbescherming tegen bestraffing in het strafrecht en het bestuursrecht. Een rechtsvergelijking tussen het Nederlandse strafrecht en het bestraffende bestuursrecht, mede in Europees perspectief (diss. Rotterdam), Deventer: Kluwer 2011, p. 8 en 9 en H.E. Bröring en G.T.J.M. Jurgens, 'De bestuurlijke boete is zo gek nog niet', NTB 2006, p. 340 en 348.

21. G.T.M. Jurgens, Het wetsvoorstel OM-afdoening en de verhouding tussen strafrechtelijke en bestuurlijke handhaving, Nijmegen: Wolf Legal Publishers 2007, p. 48 en 62

22. A.R. Hartmann, Over de grenzen van de dogmatiek en into fuzzy law (oratie Rotterdam), Apeldoorn/Antwerpen: Maklu 2011.

23. T. Barkhuysen, 'Herijking van waarborgen bij bestuurlijke sancties', NJB 2014/136.

24. Art. 1 van de Regeling van de Staatssecretaris van veiligheid en justitie tot wijziging van de Regeling vaststelling administratiekosten 2012, Stcrt. 2015, 37447

25. Kamerstukken // 2008-2009, 31 386, nr. 8, p. 16 en 17.

26. M. Barels, Hoofdlijnen van de wet mulder, Studiepockets strafrecht 4de druk 2010, p. 26.

27. Rb. Amsterdam 9 februari 2012, LJN:BV6243. 
van administratiekosten een deugdelijke wettelijke basis heeft en dat het de rechter niet is toegestaan de innerlijke waarde of de billijkheid van de wet te beoordelen (art. $11 \mathrm{AB}$ ) en dat hij slechts kan toetsen of internationale regelgeving in de weg staat aan het doorberekenen van administratiekosten. ${ }^{28}$ Van dit laatste is volgens het hof geen sprake omdat bij deze doorberekening geen sprake is van strijd met het nemo tenetur-beginsel of van dubbele bestraffing (ne bis in idem), omdat het doorberekenen van administratiekosten moet worden beschouwd als een door de wetgever aan het opleggen van een verkeersboete gekoppeld gevolg. Deze doorberekening strekt ertoe de kosten van inning van verkeersboetes bij de betrokkene an wie de sanctie is opgelegd te leggen. ${ }^{29}$ Tevens heeft het hof in twee andere zaken bevestigd, dat de kantonrechter het door de betrokkene ingestelde beroep pas in behandeling mag nemen na het stellen van de vereiste zekerheid vermeerderd met de administratiekosten en dat het de kantonrechter niet vrij staat het doorberekende bedrag aan administratiekosten te halveren. ${ }^{30}$

Deze opvatting is van belang in het geval dat de verkeersboete en de administratiekosten niet tijdig worden betaald. Dan bevat de Wahv een eigen inningstraject dat aanzienlijk strenger is dan de regeling in artikel $24 \mathrm{~b} \mathrm{Sr}$. Deze laatste regeling is van toepassing bij het niet tijdig betalen van strafrechtelijke geldboetes maar uitgesloten voor de inning van verkeersboetes omdat de Wahv voorzieningen van strafrechtelijke en strafvorderlijke aard uitsluit (in art. 2 lid 1). Ook in vergelijking met de regeling in artikel 4:113 van de Awb is het inningstraject in de Wahv aanzienlijk strenger. Bij niet tijdige betaling van verkeersboetes volgt van rechtswege een eerste verhoging van $50 \%$ (art. 23 lid $1 \mathrm{Wahv}$ ). Wordt vervolgens nog niet tijdig betaald, dan volgt een aanmaning tot het betalen van het inmiddels verhoogde bedrag (art. 24) en volgt een tweede verhoging van 100\% (art. 25 lid 1 Wahv). Deze verhogingen betreffen het kale bedrag van de opgelegde verkeersboete en de administratiekosten (art. 23 lid 1 en 25 lid 1 Wahv). Na deze twee verhogingen is het bedrag van de opgelegde verkeersboete meer dan verdubbeld. Daarnaast kan het bedrag van de verkeersboete nog flink oplopen door de invorderingskosten die worden gemaakt in het kader van het verhaal van de verkeersboete (art. 26 lid 9 en 27 lid 7 Wahv). Dit verhaal kan krachtens dwangbevel worden gedaan op de goederen van de betrokkene aan wie een verkeersboete is opgelegd dan wel zonder dwangbevel op diens inkomsten, uitkeringen en banktegoed (art. 26 lid 1 en 27 lid 1 Wahv). De keuze voor al dan niet toepassen van verhaal met dwangbevel staat ter beoordeling van de officier van justitie, maar het zonder enige redelijke grond kiezen voor de doorgaans voor de betrokkene duurdere optie van toepassing van verhaal met dwangbevel kan leiden

28. Hof Leeuwarden 14 januari 2011, LJN:BP2962

29. Hof Leeuwarden 15 juni 2012, LJN:BW8480.

30. Hof Leeuwarden 29 maart 2011, LJN:BR1296 en 29 juni 2011, LJN:BV2281. tot strijd met het zorgvuldigheids- en evenredigheidsbeginsel. $^{31}$

\section{De hoogte van de verkeersboete}

De bijlage bij de Wahv bevat de verkeersgedragingen die met een verkeersboete mogen worden afgedaan. Per gedraging wordt de hoogte van de toepasselijke verkeersboete genoemd. Volgens de Aanwijzing administratiefrechtelijke handhaving verkeersvoorschriften mocht per gebeurtenis aan de betrokkene voor ten hoogste drie gedragingen een verkeersboete worden opgelegd. ${ }^{32}$ Omdat de geldigheidsduur van deze Aanwijzing is verlopen op 31 december 2013 lijkt het er sindsdien op dat de cumulatie van verkeersboetes onbegrensd is. Het uitgangspunt is dat de politie die een in de bijlage genoemde gedraging constateert aan de betrokkene een verkeersboete oplegt volgens een tevoren bepaald en wettelijk vastgesteld tarief. ${ }^{33}$ Dit tarief bedroeg bij invoering van de Wahv maximaal 500 gulden per gedraging. Maar de hoogte van deze verkeersboetes is de afgelopen kwart eeuw diverse keren verhoogd. Het maximum bedraagt momenteel meer dan $€ 400$, voor bijvoorbeeld aanzienlijke snelheidsoverschrijdingen in gevaar zettende omstandigheden. ${ }^{34}$ Daarmee zijn deze boetes hoger dan die voor enkele misdrijven, zoals een verbale bedreiging (art. $285 \mathrm{Sr}$ ) of een eerste winkeldiefstal (art. $310 \mathrm{Sr}$ ) die volgens de oriëntatiepunten van het Landelijk overleg van voorzitters van de strafsectoren met $€ 250$ respectievelijk $€ 200$ worden bestraft. Daarmee lijkt de hoogte van deze Wahv-boetes niet in verhouding. 35

Het aanvankelijke uitgangspunt van de wetgever dat het bij de Wahv-afdoening enkel zou gaan om ethisch neutrale gedragingen van geringe ernst lijkt ook verlaten. Dijkstra wijst in verband hiermee op het wijzigingsbesluit van de bijlage van de Wahv van 15 december $2011^{36}$ waarin een forse verhoging $(55 \%)$ van alle boetetarieven voor bepaalde volgens de wetgever 'asociale en gevaarlijke gedragingen' is ingevoerd. Met deze wijziging is uitvoering aangegeven aan een motie van het parlement om te kiezen voor een gerichte boeteverhoging voor in het bijzonder snelheidsovertredingen in woonwijken, hufterigheid in het verkeer, zoals het inhalen en niet verlenen van voorrang op een zebrapad en recidive. ${ }^{37}$ Met de invoering van de 'hufterigheid' als onderscheidend criterium voor de hoogte van de ver-

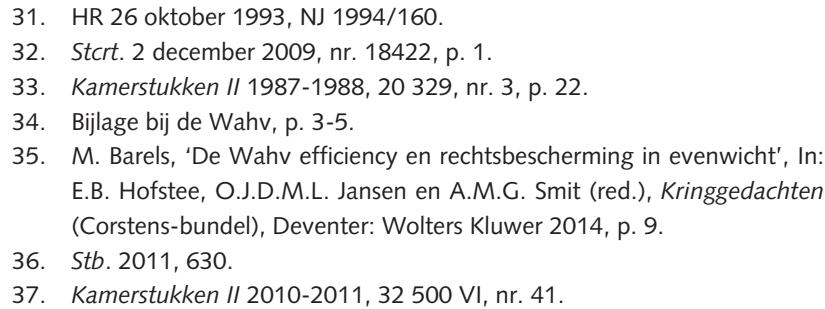


keersboete is volgens Dijkstra de vraag gerechtvaardigd of het in de Wahv nog wel gaat om ethisch neutrale verkeersvoorschriften, waaraan een vast bedrag als sanctie kan worden gekoppeld. ${ }^{38}$ Hij wijst eveneens op de handhaving van de Wet aansprakelijkheidsverzekering motorrijtuigen (WAM) die in 2011 onder de Wahvafdoening is ondergebracht. ${ }^{39}$ Dit om invulling te geven aan de wens van het College van procureurs-generaal om de handhaving te intensiveren van de in artikel 30 lid 2 WAM geregelde verplichting om een verzekering voor een motorrijtuig af te sluiten. Deze wens is ingegeven door de efficiencyvoordelen die de Wahv-afdoening zou hebben boven de strafrechtelijke afhandeling. ${ }^{40}$ Maar Dijkstra merkt terecht op dat van het niet voldoen aan de verzekeringsverplichting voor kentekenhouders van motorrijtuigen moeilijk kan worden volgehouden dat het hierbij gaat om een ethisch neutrale gedraging. ${ }^{41}$ Het niet voldoen aan deze verplichting frustreert immers gerechtvaardigde civielrechtelijke aanspraken van verkeersslachtoffers.

Voor de Wahv-afdoening is voorts kenmerkend dat de hoogte van de verkeersboete is gefixeerd. Dat wil zeggen dat er door de politie niet van mag worden afgeweken, zelfs niet vanwege de geringe gevaarzetting die door de gedraging is veroorzaakt. ${ }^{42}$ Hetzelfde lijkt te gelden voor de Wahv-rechter. Het staat hem niet vrij zich een oordeel te vormen over de redelijkheid van de verhouding tussen de door de wetgever bepaalde hoogte van de verkeersboetes en de ernst van de gedragingen. ${ }^{43}$ Niettemin lijkt er enige ruimte te zijn tot afwijking van de in de bijlage genoemde hoogte van de verkeersboete indien spra$\mathrm{ke}$ is van bijzondere omstandigheden. Dan mag de verkeersboete worden gematigd op grond van de overweging dat de officier van justitie had moeten beslissen dat de omstandigheden waaronder de gedraging heeft plaatsgevonden, het opleggen van een verkeersboete niet billijken of dat hij gelet op de persoonlijke omstandigheden van de betrokkene een lagere verkeersboete had moeten vaststellen (art. 9 lid 2 achter b Wahv). ${ }^{44}$ Voor het overige valt een beoordeling van de door de wetgever vastgestelde hoogte van de verkeersboetes en de periodieke verhogingen van deze boetes buiten het bereik van de Wahv-rechter. ${ }^{45}$ Deze mag de boete niet verlagen enkel vanwege de geringe draagkracht van de betrokkene. ${ }^{46}$ Er lijkt evenmin ruimte voor de opvatting dat in drie jaren te hoge verhogingen van verkeersboetes zijn doorgevoerd en dat deze onverbindend moeten worden geacht. ${ }^{47}$ Het is zo dat de verkeersboetes enige malen fors zijn verhoogd en deze verhogingen mede zijn

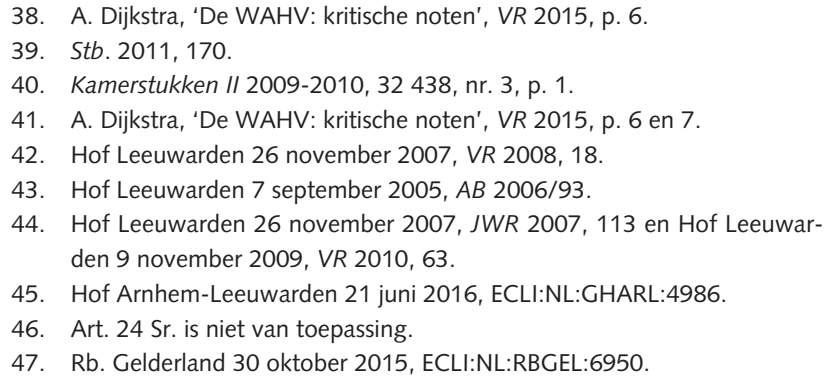

ingegeven door financiële motieven van de minister van Veiligheid en Justitie. ${ }^{48}$ Maar deze verhogingen en de daaraan ten grondslag liggende motieven hebben iedere keer de instemming van de Staten-Generaal gehad. Daarnaast lijkt artikel 2 lid 5 Wahv niet in de weg te staan aan een verhoging van verkeersboetes ten behoeve van de schatkist. ${ }^{49}$

\section{Dwangmiddelen}

De regering meende ten tijde van invoering van de Wahv dat met de verhaalsmogelijkheden, genoemd in de artikelen 26 en 27 Wahv, niet kon worden volstaan. Daarom voorziet de Wahv in de toepassing van drie dwangmiddelen indien niet of niet volledig verhaal heeft plaatsgevonden: buitengebruikstelling van het voertuig, inneming van het rijbewijs en gijzeling. De dreiging van de toepassing van deze dwangmiddelen en de kosten die daaraan verbonden zijn zullen naar de verwachting van de regering veelal voldoende zijn om de betrokkene tot betaling van de opgelegde verkeersboete(s) te bewegen. ${ }^{50}$ De drie dwangmiddelen zijn niet bedoeld als (vervangende) sancties. ${ }^{51}$ De plicht tot betalen blijft bestaan ook als de dwangmiddelen zijn toegepast en deze geen effect hebben gehad. Deze regeling is vergelijkbaar met die van de lijfsdwang bij ontneming van het wederrechtelijk verkregen voordeel (art. 36e Sr). De toepassing van lijfsdwang heft eveneens de verschuldigdheid van het geldbedrag aan de Staat ter ontneming van wederrechtelijk verkregen voordeel niet op (art. 577c lid $6 \mathrm{~Sv})$.

Deze drie dwangmiddelen behoren aan rechtsbeginselen als proportionaliteit en subsidiariteit te voldoen. Maar doen zij dat ook? Het is de vraag. Voor de buitengebruikstelling van het voertuig en de inneming van het rijbewijs geldt dat zij sinds 1997 zonder machtiging van een rechter mogen worden toegepast door de officier van justitie bij het arrondissementsparket NoordNederland. De officier van justitie zal zijn bevoegdheden in de praktijk doorgaans mandateren aan het CJIB. Uit een oogpunt van rechtsbescherming lijkt de (in 1997 vervallen) regeling van een voorafgaande rechterlijke machtiging voor deze twee dwangmiddelen beter dan de huidige regeling omdat in geen enkel ander rechtsgebied aan een boete-opleggend bestuursorgaan zulke verregaande bevoegdheden zijn toegekend om de incasso te vergemakkelijken. In navolging van Barels lijkt het mij dat vergaande bevoegdheden enkel kunnen worden toe-

48. De opbrengsten van verkeersboetes zijn aanzienlijk, in 2013 meer dan 1 miljard euro: www.verkeersmaatregelen.nl/dossier verkeersovertredingen.

49. Zo ook: Rb. Overijssel 11 november 2015, NJFS 2016/26 en de minister van Veiligheid en Justitie: Kamerstukken // 2015-2016, 29 398, nr. 483, p. 1.

50. Kamerstukken I/ 1987-1988, 20 329, nr. 6, p. 10.

51. R.W.M. Craemer, 'De eerste bedrijfsresultaten onder de Wet Mulder', in: J.W. van der Hulst, De Wet Mulder in bedrijf, Arnhem: Wolters Kluwer 1994, p. 21. 
gekend na rechterlijke toetsing, zodat een terugkeer naar de situatie van voor 1997 zou moeten worden overwogen. ${ }^{52}$ Daarnaast wijst Sackers erop dat er voor een eigen systeem van dwangmiddelen in de Wahv geen plaats meer is en dat er dient te worden angesloten bij de regeling van alle andere bestuurlijke boetes in de Awb. ${ }^{53}$

De Wahv bevat geen rangorde van de dwangmiddelen. Op grond van de memorie van toelichting ${ }^{54}$, het zorgvuldigheidsbeginsel en het subsidiariteitsbeginsel lijkt echter bij de uitoefening van de dwangmiddelen de toepassing van gijzeling als laatste in aanmerking te komen omdat het bij uitstek - vanwege het vrijheidsbenemende karakter ervan - het zwaarste dwangmiddel is voor de betrokkene. Toepassing van gijzeling leidt immers tot vrijheidsberoving zolang de verkeersboete niet is betaald.

Bij de buitengebruikstelling (art. 28b Wahv) gaat het om een voertuig van de betrokkene dan wel van een soortgelijk voertuig dat hij gebruikt. Dit laatste betreft de situatie dat de betrokkene in de tussentijd een ander voertuig aanschaft. De effectuering van de buitengebruikstelling vindt plaats door het wegslepen van het voertuig of het aanbrengen van een wielklem. ${ }^{55}$ Deze buitengebruikstelling mag maximaal vier weken duren. Nadat een voertuig buiten gebruik is gesteld, wordt dit zo spoedig mogelijk aan de kentekenhouder kenbaar gemaakt. Aan hem wordt de mogelijkheid geboden binnen één week de verkeersboete(s), de administratiekosten, de verhogingen en de kosten van buitengebruikstelling geheel te voldoen. ${ }^{56}$

Bij de inneming van het rijbewijs (art. 28a Wahv) gaat het om het rijbewijs van de betrokkene aan wie een verkeersboete is opgelegd. Dan kan een eventueel aanwezig rijbewijs worden ingenomen om voldoening van de verkeersboete en de kosten te bevorderen. De periode dat het rijbewijs mag worden ingenomen is bepaald op vier weken. Het rijbewijs wordt teruggegeven zodra de verkeersboete is betaald. Dit dwangmiddel is niet beperkt tot de gevallen waarin de Wahv-gedraging met een motorvoertuig is begaan, maar omvat ook het geval van een fietser of voetganger die de opgelegde verkeersboete(s) niet betaalt. In dit laatste geval lijkt er echter sprake van een disproportioneel gebruik van het dwangmiddel in relatie tot de beboete gedraging die immers niet met een rijbewijsplichtig voertuig is verricht. Toepassing van dit dwangmiddel zou in dit geval pas mogen plaatshebben na een verkregen rechterlijke machtiging.

M. Barels, Hoofdlijnen van de wet mulder, Studiepockets strafrecht 4de druk, Deventer: Wolters Kluwer 2010 p. 72.

53. H.J.B. Sackers, 'De Wet Mulder mag geen kathedraal van de twintigste eeuw worden', Special 25 jaar Wahv, VR 2016, p. 89.

54. Kamerstukken II,1987-1988, 20 329, nr. 3, p. 50.

55. Kamerstukken II, 1987-1988, 20 329, nr. 3, p. 49 en 50.

56. Aanwijzing feit gecodeerde misdrijven, overtredingen en Muldergedraging van 1 januari 2016, Stcrt. 2015, 46384, p. 2 (par. 7).

\section{Gijzeling}

Gijzeling mag slechts worden toegepast na een daartoe verkregen machtiging van de kantonrechter op vordering van de officier van justitie bij het arrondissementsparket Noord-Nederland. Tegen de verleende machtiging staat geen hoger beroep open (art. 28 lid 2 Wahv) en de voorgenomen gijzeling kan enkel aan de civiele rechter worden voorgelegd. ${ }^{57}$ De vordering en tenuitvoerlegging van gijzeling omdat de betrokkene de aan hem opgelegde verkeersboetes niet heeft betaald, is niet in strijd met artikel 5 EVRM en van de rechtmatigheid van de gijzeling moet worden uitgegaan, zodat een buiten de Wahv aangezochte voorzieningenrechter slechts onder bijzondere omstandigheden de gijzeling mag beëindigen. ${ }^{5}$ Gijzeling mag voor ten hoogste een week per gedraging worden toegepast. Bij een groot aantal gedragingen die op dezelfde betrokkene betrekking hebben, kan de totale gijzelingsduur aanzienlijk oplopen. Maar het landelijk overleg van kantonrechters gaat ervan uit dat van een gijzeling van in totaal 15 dagen zoveel pressie uitgaat om te betalen, dat bij een vordering tot machtiging tot het toepassen van gijzeling van langere duur zal moeten blijken van bijzondere omstandigheden die een langere totaalduur rechtvaardigen..$^{59}$ De toepassing van gijzeling ontslaat de betrokkene niet van de verplichting tot volledige betaling van de verkeersboete(s). Blijft dit ook na toepassing van gijzeling achterwege, dan mag de officier van justitie overwegen opnieuw verhaal te zoeken op de activa van de betrokkene of een (ander) dwangmiddel toepassen. ${ }^{60}$ Indien wederom wordt gekozen voor gijzeling, dan is er een nieuwe machtiging van de kantonrechter nodig. ${ }^{61}$ De kantonrechter geeft voor gijzeling geen toestemming zonder de betrokkene te hebben gehoord, althans behoorlijk te hebben opgeroepen. Gijzeling is geen vervangende sanctie, zoals bijvoorbeeld vervangende hechtenis. ${ }^{62}$ De verplichting tot betaling van de opgelegde verkeersboete blijft bestaan.

\section{Problemen bij toepassing gijzeling}

Het komt regelmatig voor dat de betrokkene de hem opgelegde verkeersboete(s) niet betaalt. In de afgelopen jaren werd in ongeveer 7\% van de opgelegde verkeersboetes een dwangmiddel toegepast. Omdat er ruim

57. Hof Leeuwarden 23 maart 2011, JWR 2011, 73

58. Rb. Leeuwarden 4 januari 2005, VR 2005, 154 en Hof Amsterdam 13 september 2011, VR 2013, 18.

59. Ktg. Breda 18 juni 1999, VR 2002, 26. Indien sprake is bijzondere omstandigheden mag de gijzeling langer duren: zie Hof Den Haag 21 juli 2015, ECLI:NL:GHDHA:2015:2048, al lijkt een gijzelingsduur van 126 dagen te lang: Rb. Den Haag 28 maart 2014, ECLI:NL:RBDHA: 2014:6337.

60. Kamerstukken // 1987-1988, 20 329, nr. 3, p. 50.

61. Kamerstukken // 1987-1988, 20 329, nr. 6. p. 11.

62. Art. $24 \mathrm{c}$ lid $6 \mathrm{Sr}$ is niet van toepassing. 
8 miljoen verkeersboetes per jaar ${ }^{63}$ worden opgelegd, gaat het om meer dan een half miljoen zaken per jaar. Van deze zaken werd in de afgelopen jaren bij ruim 80.000 zaken op jaarbasis een vordering gedaan door het Openbaar Ministerie om gijzeling te mogen toepassen. Deze vordering wordt in ongeveer de helft van de gevallen door de kantonrechter toegewezen. ${ }^{64}$ Dit betekent dat de betrokkene wordt ingesloten totdat hij de verkeersboete heeft betaald. Dit blijkt voor een aanzienlijk aantal betrokkenen een probleem te zijn, omdat deze niet over de benodigde financiën beschikken om het bedrag van verkeersboete (en de administratiekosten en de daarop toegepaste verhogingen en de invorderingskosten van het verhaal) te betalen. In deze gevallen lijkt het niet zinvol om gijzeling te vorderen zonder enig onderzoek naar de oorzaken van de betalingsonmacht van de betrokkene en de haalbaarheid van de inning van de aan hem opgelegde verkeersboetes.

In de praktijk lijkt het een automatisme dat gijzeling wordt gevorderd indien sprake is van niet betaalde verkeersboetes, ook in het geval van betalingsonmacht van de betrokkene. Ter zitting wordt de kantonrechter geconfronteerd met deze betalingsonmacht, terwijl doorgaans een inhoudelijke toelichting door het Openbaar Ministerie over de financiële situatie van de betrokkene ontbreekt. Behoort de kantonrechter daar dan zelf onderzoek naar te doen? Dat is lastig, omdat de betrokkene vaak niet komt opdagen bij de behandeling van de vordering tot gijzeling. Het lijkt ook niet op de weg te liggen van de kantonrechter om dit te doen omdat uit een oogpunt van zorgvuldigheid mag worden verwacht dat het Openbaar Ministerie de kantonrechter voorziet van informatie over de individuele omstandigheden van de betrokkene, inclusief een analyse van de financiële situatie van de betrokkene. Dit gebeurt echter niet of nauwelijks. Het Openbaar Ministerie vordert standaard gijzeling indien de voorafgaande inningsinspanningen niet tot betaling van verkeersboetes hebben geleid. De kantonrechter moet het dan zelf maar uitzoeken. De verdeling van de bewijslast wordt hier uit het oog verloren.

Deze gang van zaken is diverse keren gehekeld door een kantonrechter in de Rechtbank Breda. In 2007 besliste deze dat een vordering tot gijzeling moest worden afgewezen, omdat de betrokkene zelf een betalingsregeling heeft getroffen met het CJIB, bestaande uit twaalf termijnen van $€ 50$ per maand, en uit haar persoonlijke omstandigheden sprake bleek van betalingsonmacht. ${ }^{65}$ De officier van justitie die gijzeling vordert zonder enige onderbouwing en met voorbijgaan aan de melding van een deurwaarder dat geen verhaalsmogelijkheden aanwezig zijn, handelt volgens deze kantonrechter in strijd

63. In meer dan $80 \%$ gaat het om een verkeersboete voor een snelheidsovertreding: Jaaroverzicht verkeer 2015 Ministerie van Veiligheid en Justitie, 4 februari 2016.

64. NO, Gegiizeld door het systeem, rapportnummer 2015/160, p. 3, 11 en 12.

65. Rb. Breda 7 juni 2007, JWR 2007, 73. met het zorgvuldigheids- en motiveringsbeginsel. ${ }^{66}$ In 2013 wees de kantonrechter voorts diverse keren een vordering tot gijzeling af, omdat de gerechtsdeurwaarder geen verhaalsmogelijkheden aanwezig achtte in het geval van een betrokkene die ongeveer $€ 50.000$ aan schulden heeft ${ }^{67}$ en in een ander geval omdat op het aanbod van de betrokkene aan het Openbaar Ministerie en het CJIB om een betalingsregeling te treffen stelselmatig niet is gereageerd. ${ }^{68} \mathrm{Hij}$ plaatste vraagtekens bij het gemak waarmee deze vorderingen op grote schaal worden gedaan. ${ }^{69} \mathrm{En}$ in $2014 \mathrm{kreeg}$ deze kantonrechter te maken met een betrokkene die niet in staat was de opgelegde verkeersboetes te betalen en al vier jaar had geprobeerd om het kenteken van een scooter die niet meer van haar was van haar naam te krijgen, ondanks het inschakelen van haar advocaat en de nationale ombudsman. Het opnieuw vorderen van gijzeling door de officier van justitie zonder melding te maken van deze omstandigheden is volgens de kantonrechter in strijd met het subsidiariteitsbeginsel. ${ }^{70}$

Ook andere kantonrechters zijn ertoe overgegaan het standaard vorderen van gijzeling af te wijzen. Daarbij is de kernoverweging dat de doelstelling van gijzeling betekent dat sprake moet zijn van een reële verwachting dat de betrokkene in staat is de verkeersboetes te betalen terwijl bij betalingsonmacht het doel van gijzeling niet zal kunnen worden bereikt. ${ }^{71}$ De omstandigheid dat de betrokkene in het verleden wel verkeersboetes heeft betaald maakt dit niet anders, en betalingsonwil moet door de officier van justitie afdoende worden aangetoond. ${ }^{72}$ Daarnaast ligt het bij betalingsonmacht van de betrokkene volgens diverse kantonrechters veeleer voor de hand de opgelegde verkeersboetes (gedeeltelijk) kwijt te schelden en/of een betalingsregeling af te spreken. ${ }^{73}$ Een gehele kwijtschelding ligt voor de hand in het geval van automatisch opgelegde verkeersboetes aan een betrokkene die de tenaamstelling van haar auto niet kan wijzigen omdat de overheid haar auto al jaren geleden in beslag had genomen. ${ }^{74}$

Het aangaan van een betalingsregeling is bij invoering van de Wahv geblokkeerd. Het voordeel van de betrokkene om het bedrag van de verkeersboete(s) in termijnen te kunnen betalen, woog volgens de regering niet op tegen de problemen die daarmee in de praktijk van de inning van strafrechtelijke boetes vaak bleken te bestaan. ${ }^{75}$ Vorig jaar zomer heeft de staatssecretaris van Veiligheid en Justitie aangekondigd wettelijk vast te leg-

66. Rb. Breda 27 juli 2012, VR 2013, 21

67. Rb. Zeeland-West-Brabant 28 maart 2013, JWR 2013, 60.

68. Rb. Zeeland-West-Brabant 25 juli 2013, ECLI:6073.

69. Rb. Zeeland-West-Brabant 28 maart 2013, NJFS 2013/157 en 25 juli 2013, ECLI:6072.

70. Rb. Zeeland-West-Brabant 11 december 2014, ECLI:9017.

71. Rb. Haarlem 21 september 2012, JWR 2012, 105 m.nt. JvdH en Rb. Den Haag 10 december 2015, ECLI:14570 en 14572.

72. Rb. Amsterdam 28 april 2015, ECLI:2759 en 12 mei 2015, ECLI:2757, 2758 en 2764.

73. Rb. Noord-Holland, 6 september 2013, ECLI:9343.

74. Rb. Noord-Holland 27 september 2013, ECLI:9341.

75. Kamerstukken // 1987-1988, 20 329, nr. 3, p. 48. 
gen dat verkeersboetes vanaf $€ 225$ in termijnen kunnen worden betaald. ${ }^{76}$ Per 1 juli 2015 is dit voornemen gerealiseerd en kunnen kale verkeersboetes vanaf dit bedrag (d.w.z. zonder de administratiekosten) in drie termijnen worden betaald indien daartoe contact wordt opgenomen met het CJIB. ${ }^{77}$ Hiermee is voldaan aan de wens van de nationale ombudsman om bij het aangaan van een betalingsregeling duidelijk te maken aan de betrokkene tot welke overheidsinstantie hij zich kan wenden. ${ }^{78}$ En met deze betalingsregeling is tevens meer aansluiting gevonden bij de regeling die geldt voor de betaling van strafrechtelijke geldboetes (art. 24a Sr).

\section{De nationale ombudsman over gijzeling}

De kritiek van kantonrechters op de praktijk van het standaard vorderen van gijzeling in het geval van betalingsonmacht van de betrokkene alsmede diverse klachten van betrokkenen heeft de nationale ombudsman ertoe gebracht om nader onderzoek te doen naar de inning van verkeersboetes. Hij heeft vastgesteld dat gijzeling vaak is gevorderd en toegepast in gevallen waarin het beoogde doel van betaling niet kon worden gerealiseerd vanwege financiële onmacht bij de betrokkene. Gijzeling wordt doorgaans automatisch gevorderd zonder onderbouwing en zonder dat duidelijk is wat het effect is geweest van verhaal of toepassing van de overige twee dwangmiddelen. Tevens werd standaard gijzeling gevorderd van betrokkenen die zonder succes bij het CJIB uitstel hadden bepleit of hadden gevraagd om een betalingsregeling. Bij de tenuitvoerlegging van de gijzeling is voorts gebleken dat veel betrokkenen zijn ingesloten die de opgelegde verkeersboetes niet konden betalen. De nationale ombudsman is op grond hiervan van oordeel dat het Openbaar Ministerie door deze wijze van onderzoek, vorderen en tenuitvoerlegging van de gijzeling de mensenrechten onvoldoende heeft gerespecteerd. Hij pleit voor maatwerk in gevallen waarin een gestandaardiseerde inning van verkeersboetes niet voldoet. Voor deze gevallen is volgens de nationale ombudsman nadere samenwerking tussen de het CJIB, de RDW en het Openbaar Ministerie in de Wahv-afdoening aangewezen. Hij adviseert met klem dat het Openbaar Ministerie grondig onderzoek moet verrichten om duidelijk te krijgen of er bij een betrokkene sprake is van betalingsonwil of betalingsonmacht. Vervolgens moet het Openbaar Ministerie een weloverwogen beslissing nemen omtrent zijn vordering tot gijzeling, waarbij het uitgangspunt moet zijn dat gijzeling slechts dient te worden ingezet in gevallen van betalingsonwil. En indien het Openbaar Ministerie een vordering tot gijzeling indient bij de kantonrechter, dan behoort deze

76. Brief van de Staatssecretaris van 5 juni 2015 aan de Voorzitter van de Tweede Kamer, kenmerk 649048, p. 2.

77. www.cjib.nl/betalingsregelingwahv.

78. NO 28 juli 1998, VR 1999, 73. deugdelijk te worden gemotiveerd en voorzien te zijn van een overzicht waaruit blijkt dat minder ingrijpende middelen (verhaal en de toepassing van andere dwangmiddelen) niet tot betaling van de verkeersboete(s) hebben geleid. ${ }^{79}$

\section{De rechtsbescherming in het gedrang}

De inningspraktijk van verkeersboetes laat een beeld zien van een overheid die zich hardvochtig opstelt jegens betrokkenen die hun verkeersboetes niet (op tijd) betalen. Zodra het wettelijk mogelijk is worden deze geconfronteerd met aanzienlijke verhogingen en aan het einde van het inningstraject pleegt standaard gijzeling te worden gevorderd zonder enige belangenafweging. De balans tussen efficiënte handhaving en een redelijke rechtsbescherming van de betrokken burger lijkt daarmee te veel doorgeslagen ten koste van de rechtsbescherming. En dat is een pijnlijke constatering omdat de wetgever bij invoering van de Wahv ook de deugdelijke rechtsbescherming van de betrokkene tot doel stelde. ${ }^{80}$

Ook de recente ervaringen met het alcoholslotprogramma (ASP) maken duidelijk dat bestuurlijke handhaving in het verkeerssanctierecht niet zonder meer leidt tot een passend niveau van rechtsbescherming. Het ASP was als onderdeel van de bestuurlijke vorderingsprocedure in de Wegenverkeerswet 1994 gericht op het verminderen van het aantal verkeerslachtoffers als gevolg van rijden onder invloed. In de praktijk leidde toepassing van dit programma tot hoge kosten voor de betrokken bestuurder (meer dan $€ 5.000$ ) en een standaardafdoening waarbij geen onderscheid werd gemaakt tussen gevallen waarbij oplegging van een ASP wel of geen ingrijpende gevolgen had voor deze bestuurder. Op grond hiervan heeft de Raad van State vorig jaar de regelgeving die ten grondslag ligt aan oplegging van het ASP onverbindend verklaard wegens strijd met het evenredigheidsbeginsel zoals bedoeld in artikel 3:4 lid 2 Awb. ${ }^{81}$ De Hoge Raad had een dag eerder al bepaald dat een strafvervolging wegens rijden onder invloed van alcohol in strijd was met de beginselen van een goede procesorde, indien aan de verdachte voor hetzelfde feit een ASP is opgelegd. ${ }^{82}$ Daarop hebben de verantwoordelijke ministers besloten om het ASP niet meer te laten opleggen voor nieuwe gevallen en het programma volledig te schrappen. ${ }^{83}$ Met het invoeren van het ASP zonder goed na te denken over de mensenrechtelijke kanten lijkt de wetgever zijn hand te hebben overspeeld. Hier-

79. NO, Gegijzeld door het systeem, rapportnummer 2015/160, p. 47, 48 50-52 en 54.

80. Kamerstukken II, 1987-1988, 20 329, p. 8.

81. ABRvS 4 maart 2015, VR 2015, 45, bevestigd in ABRvS 11 maart 2015, ECLI:723.

82. HR 3 maart 2015, VR 2015, 47.

83. Kamerstukken II, 2014/15, 29 398, nr. 425 en Kamerstukken II 2015-2016, 29 398, nr. 495, p. 4. 
over te bezinnen, eer te beginnen is misschien wel de belangrijkste les die uit een reconstructie van de opkomst en ondergang van het ASP valt te trekken. ${ }^{84}$ De uitvoeringspraktijk van dit programma bleek (te) rigide en de rechtsbescherming had (te) weinig inhoud, zodat het daarmee een product van het spook van de sanctiestaat leek. ${ }^{85}$

In de inningspraktijk van verkeersboetes, vooral als deze uitmondt in een vordering tot gijzeling van de betrokkene, lijkt eveneens sprake te zijn van een (te) rigide grondhouding van de inningsinstanties. Een houding die leidt tot het standaard vorderen van gijzeling in het geval van betalingsonmacht van de betrokkene lijkt echter niet langer houdbaar. De met ingang van 2015 breed gedeelde opvatting onder kantonrechters is dat in een dergelijk geval de vordering tot gijzeling behoort te worden afgewezen. Tevens wijst de nationale ombudsman erop dat maatwerk is aangewezen in gevallen van cumulatie van verkeersboetes die de financiële situatie van een betrokkene aanzienlijk onder druk zetten. Dit betekent (meer) afstemming tussen de betrokken instanties in het inningstraject en een plicht voor het Openbaar Ministerie om aan het einde van dit traject te komen tot een afgewogen keuze voor de vordering tot gijzeling. Een vordering die slechts realistisch is indien de betrokkene in staat is om de aan hem opgelegde verkeersboetes te betalen. En ook dan mag van het Openbaar Ministerie worden verwacht dat het motiveert waarom gijzeling het aangewezen dwangmiddel is.

Daarnaast is van belang op te merken dat de Wahvinning van verkeersboetes sinds 1990 als een bestuurlijke afdoening is ingericht. Het gevolg hiervan is dat deze afdoening moet voldoen aan de beginselen van behoorlijk bestuur. Het standaard vorderen van gijzeling bij onbetaalde verkeersboetes valt lastig te rijmen met het zorgvuldigheidsbeginsel (art. 3:2 Awb), het beginsel van een evenredige belangenafweging (art. 3:4 Awb), en het motiveringsbeginsel. Deze beginselen verplichten de inningsinstanties tot een afgewogen en controleerbaar beleid dat ten grondslag dient te liggen aan de inning van verkeersboetes in een concreet geval. Helaas blijkt dit in de dagelijkse inningspraktijk van de afgelopen jaren niet of nauwelijks voor te komen. Dit klemt te meer bij een gevorderde gijzeling waar standaard geen onderscheid wordt gemaakt tussen betalingsonmacht en betalingsonwil bij de betrokkene.

\section{Naar een andere inningspraktijk}

Het lijkt onvermijdelijk over te stappen op een andere wijze van inning van verkeersboetes. $\mathrm{Al}$ vroeg in het inningstraject zou daartoe door het CJIB gesignaleerd kunnen worden dat er bij de betrokkene sprake is van betalingsonmacht. Deze informatie kan worden doorgegeven aan de Centrale Verwerking Openbaar Ministerie (CVOM) die sinds medio 2014 centraal toezicht houdt op de inning van verkeersboetes en de kwaliteit van de (onderbouwing van de) vorderingen tot gijzeling. Tevens wordt gekeken naar de meest effectieve aanpak, waarbij het uitgangspunt dient te zijn dat enkel de betrokkene die wel kan, maar niet wil betalen een vordering tot gijzeling tegemoet kan zien. ${ }^{86}$ Hiermee lijkt gebroken met de gewoonte om automatisch het inningstraject te vervolgen indien de verkeersboete niet wordt betaald. In plaats daarvan zou (door het CVOM) moeten worden gekeken naar alternatieven zoals een betalingsregeling in termijnen en wellicht een gedeeltelijke kwijtschelding in gevallen waarin de betrokkene vanwege een grote schuldenlast ook op langere termijn onmachtig zal zijn om de verkeersboetes te kunnen betalen. Deze kwijtschelding zou dan betrekking kunnen hebben op de verhogingen, de administratiekosten en de kosten van verhaal, zodat enkel het kale bedrag van de opgelegde verkeersboete(s) overblijft. Indien toch wordt besloten tot een vordering tot gijzeling, zou op het Openbaar Ministerie de (bewijs)last dienen te rusten dat alternatieve wijzen van inning van verkeersboetes zijn uitgeprobeerd dan wel uitgesloten en dat er goede redenen zijn voor toepassing van dit dwangmiddel. Dit laatste lijkt ondenkbaar indien sprake is van een betrokkene die vanwege financieel onvermogen de opgelegde verkeersboete(s) niet kan betalen en bij wie op korte termijn niet is te verwachten dat deze situatie verandert.
84. M. den Houdijker, 'Het alcoholslotprogramma, de rechter en artikel 6 EVRM: Over de opkomst en ondergang van een bestuursrechtelijk (straf) maatregel', NJCM 2016, p. 146-147.

85. H.J.B. Sackers, ““Fuzzy law” rondom het alcoholslot', Trema 2014, p. 189.
86. J. Meerdink en A.J. Rijks, 'Parket CVOM binnen 25 jaar Wahv', Special 25 jaar Wahv, VR 2016, p. 99. 